On Tuesday, society members recreated the 1 July 1858 reading at the Royal Academy on Piccadilly. Darwin went on to develop his idea, publishing his seminal work On the Origin of Species by Means of Natural Selection in 1859, whereas Wallace slipped into relative obscurity (see Nature 453, 1188-1190; 2008).

\section{Final decision expected on European stem-cell patent}

The highest authority of the European Patent Office (EPO), the Enlarged Board of Appeal, will make a final decision within the next few weeks about whether human embryonic stem cells can be patented in Europe.

A public hearing at the EPO's headquarters in Munich, Germany, last week considered a 1996 patent application by the Wisconsin Alumni Research Foundation (WARF) that covered methods of cultivating primate embryonic stem cells, as well as the cell lines themselves. WARF appealed after its application was rejected in 2004. The EPO disallows any patenting on "uses of human embryos for industrial or commercial purposes".

The board's decision will affect not only the Wisconsin patent, but at least 41 similar pending patents in Europe.

\section{Spain awards apes legal rights}

The Spanish parliament's environment committee last week approved resolutions for chimpanzees, gorillas and orangutans to gain some statutory rights currently applicable only to humans. It is thought to be the first time a national legislature has taken such action.

The resolutions, which passed with crossparty support and are expected to be approved as laws by the full parliament within a year, are based on the Great Ape Project, a framework designed by scientists and philosophers who believe that humans' closest biological relatives deserve the right to life, liberty and protection from torture.

The laws will ban potentially harmful research, ape trading, profiting from apes, and using apes in performances. Zoos could still legally hold apes, but living conditions must be "optimal".

\section{Pay-off agreed for expert fired after anthrax attacks}

A biological-weapons researcher will receive US\$5.85 million to drop his civil case against the US Department of Justice, which publicly named him in association with a series of anthrax attacks in 2001.

Steven Hatfill, a former employee of the US Army Medical Research Institute

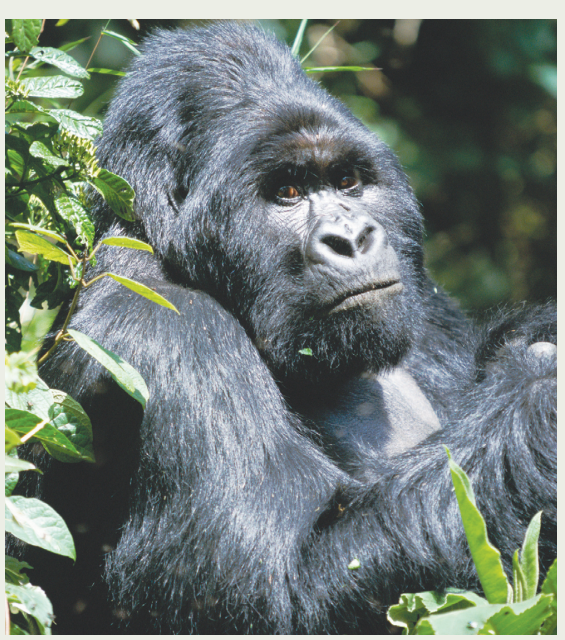

of Infectious Diseases at Fort Detrick in Frederick, Maryland, was named by thenattorney general John Ashcroft as a "person of interest" after a string of anthrax mailings to media outlets and lawmakers. Hatfill was followed, his phones were tapped and he lost his job at Louisiana State University in Baton Rouge (see Nature 419, 104; 2002).

Hatfill said that this had violated his privacy rights. As part of the terms, the government admits no wrongdoing in the case. 